\title{
Erratum
}

Food Sci. Biotechnol. 23: 401-407 (2014). DOI 10.1007/s10068-014-0055-y

\section{Effect of Ionic Strength on Soluble Protein Removal from Giant Squid Mantle (Dosidicus gigas) and Functional Evaluation of Protein Recovery}

Jose de Jesus Encinas-Arzate, Josafat Marina Ezquerra-Brauer, Victor Manuel Ocaño-Higuera, Benjamin Ramirez-Wong, Lorena Armenta-Villegas, Wilfrido Torres-Arreaola, and Enrique Marquez-Rios

Correspondence to: emarquez@guayacan.uson.mx

Erratum in: Food Sci. Biotechnol. 24: 1185 (2015). DOI: 10.1007/s10068-015-0151-7

The publisher regrets that one of co-authors' names was incorrect. The correct author's name is now shown on page 401.

Original:

Wilfrido Torres-Arreaola

This information has been replaced by

Wilfrido Torres-Arreola 